\title{
Semiosis and the Umwelt of a robot
}

WINFRIED NÖTH

\section{Does a robot have an Umwelt?}

Claus Emmeche (this issue) raises the question 'Does a robot have an Umwelt'? His answer is complex and differentiated. The concepts of Umwelt and environment, says Emmeche, are relevant to both biology and robotics. Organisms as well as robots interact with their environment in processes of semiosis. However, 'environment' must be distinguished from 'Umwelt', and Umwelt in Uexküll's sense can only be experienced by an organism, not by a robot. Furthermore, even if a robot had some experience of its Umwelt, humans could hardly ever know anything about it.

Emmeche avoids one-sided positions, and since he always does justice to the pros as well as to the cons of his arguments, it is difficult to disagree with him. However, the critique that Ricardo Gudwin (1999) has developed in reply to Emmeche and indirectly also against basic Uexküllian tenets indicates that some principles of Uexküll's Umwelt theory and their semiotic implications might have been elaborated in a more pronounced way. My own contribution to this discussion (see also Nöth 1997, 2000) aims at clarifications and at some semiotic extensions of the arguments concerning the processes of semiosis in the robot's interaction with its environment.

\section{How organisms and robots interact similarly with their environment}

There are at least four reasons why robots interact in the same way with their environment as organisms do, and these reasons support the argument that not only organisms, but also robots have an Umwelt in Uexküll's sense.

The first is that both robots and organisms differentiate between the more encompassing environment in Uexküll's sense of Umgebung and 
a local or 'subjective' environment, which Uexküll calls Umwelt. The robot whose sensor devices can only detect green objects lives in an Umwelt which consists only of green things, but this green Umwelt is only part of the more encompassing environment of green, red, and black objects, which remains inaccessible to the robot's mind, just as ultrasound, perceived by bats, remains inaudible to humans.

The second reason why not only organisms, but also robots can be said to have an Umwelt is that both process their environmental stimuli selectively. The robot that reacts to the perceptual cues of all green things while ignoring all red things perceives its environment selectively just like humans who only perceive sounds of a frequency lower than ultrasound. Robots equipped with different sensors hence perceive their environment 'subjectivity', and there is relativity in the way each type of robot processes environmental stimuli. By these characteristics, robots interact with an Umwelt in Uexküll's sense.

The third reason why robots interact with their environment like organisms do is that organisms have, and robots may have, internal representations of their Umwelt. In Uexküll's biosemiotics, the internal representation of the organism's Umwelt is called its Innenwelt. In robotics it is the robot's model or 'symbolic representation' of its environment that corresponds to the Innenwelt of an organism.

The fourth parallelism is, so to speak, an anatomical one. It is apparent when we compare a biological organism, as represented in Uexküll's model of the functional circle, with the design of a robot. Just as the biological organism is equipped with perceptual organs and receptors as well as with effector organs and effectors, the robot has perceptual modules and action modules to interact with its environment, which is hence of the nature of an Umwelt.

\section{How organisms and robots interact differently with their environment}

One of the major semiotic differences between a living organism and a robot interacting with their environments can be explained in terms of self- and alloreference. (For other differences, see Emmeche 1994: 38-43.) Life and communication are, at least to a certain degree, self-referential processes of semiosis. This idea has become a central topic in the theory of autopoietic systems since the 1970s, but the idea of self-referentiality being inherent in the organism's interaction with its Umwelt has also been implicitly elaborated in Uexküll's Theory of Meaning of 1940. The [biological] subject, according to Jakob von Uexküll is 
the point of reference for any meaning, since the value of a subject does not reside in something else, 'but rather lies in its own existence, in its own self'. It is also the center of an Umwelt, which is built up by the subject as a receiver of signs that are interpreted according to a species-specific code. (T. von Uexküll 1982: 87)

Needless to say, a machine, in spite of a certain autonomy in its agency, can never be said to have its ultimate goals within itself. The objectives of a machine have always been established from outside, namely by the engineer who designed it and the user who switches it on and off. Thus, the robot's ultimate framework of reference, its final causality, is elsewhere, and thus, the resulting semiotic process is alloreferential.

\section{Umwelt between constructivism and objectivism}

'Every subject is the constructor of its Umwelt', writes T. von Uexküll (1982: 87), thus anticipating an essential tenet of constructivism. The Umwelt of a bee that perceives red where we see yellow is constructed by the sensory organs of this bee. Uexküll (1982 [1940]: 46) argues: 'Colors are light waves that have become sensations: This means that they are not electrical stimuli to the cells of our cerebral cortex, but the egoqualities of these cells'. This constructivist line of argument culminates in the thesis 'that the constancy of matter is also illusory' (1982 [1940]: 70):

Not one single property of matter remains constant when we examine the full range of Umwelts. Each object we observe not only changes its meaning-quality from one Umwelt to another but the structure of all its material and formal properties also changes. Matter in the human Umwelt is the 'basic rock' on which the universe rests; and it is precisely this material world that vanishes from one Umwelt to the next. - No! The constancy of matter, about which the materialists boast, is not a solid base for a comprehensive view of the world. (1982 [1940]: 71)

Such constructivist arguments are incompatible with the principles of objectivism (or 'materialism', as Uexküll [1982 (1940)] called his opponents' philosophy of nature). A clearly objectivist argument against Uexküll is the one Ricardo Gudwin (1999: 52) develops in response to Emmeche, when he says: 'The subject is not the constructor of its own Umwelt ... because the Umwelt does exist in the real world, despite any influence of the system'.

The gulf between the constructivist view of a world consisting of mere 'ego-qualities' and the objectivist view of a 'real' world existing 'out there' seems to be unbridgeable. However, semiosis, according to Peirce 
is a process of mediation, and this concept of mediation provides the semiotic bridge between constructivism and objectivism since it gives a mediating account of the relation between a subject and an object in their Umwelten. Let us, therefore, consider the status of the objects in the Umwelt of an organism in the light of Peirce's semiotics.

With Peirce, it is necessary to distinguish between two kinds of objects, the dynamical and the immediate object. While the dynamical object is the object 'outside' the sign in the sense of a reality which 'by some means contrives to determine the sign to its representation' ( $C P$ 4.536), the immediate object is the way this dynamical object is symbolically represented, indexically given, or iconically presented by the sign. In other words, the immediate object comes close to the Umwelt as constructed by the organism's mind or Innenwelt, while the dynamical object is an object in its experiential Umwelt, 'regardless of any particular aspect of it' $(C P$ 8.133). In the process of semiosis, we thus do not only have the alternative of a 'real' and a 'constructed' object, but we have both the dynamical object outside the Umwelt and the immediate object within the Umwelt, which indicates, and thus gives access to, the environment beyond the Umwelt.

These two objects are present not only in biosemiosis, but they can also be present in robot semiosis. Consider a robot that is able to learn from the environment in which it moves around. The robot starts out with a program in its perceptual module which represents a world of immediate objects. It is true that the perceptual acquaintance of the Umwelt with which this robot is equipped is not a result of the robot's own previous experience with its environment, but of the programmer's simulation of such an experience. However, as soon as the robot interacts with, and learns from, its actual environment, it enters into contact with a world of dynamical objects. The actual reality of these objects is not yet represented as such within the perceptual module but can become represented in the process of trial and error. The interpretative result computed by the robot in its interactions with the dynamical objects of its environment is the interpretant in this process of semiosis. It is able to affect the robot's future interpretations of its Umwelt. In future situations, thus acquired knowledge is available as the immediate object in the robot's interaction with its Umwelt.

\section{References}

Emmeche, Claus (1994). Das lebende Spiel: Wie die Natur Formen erzeugt. Reinbek: Rowohlt. 
Gudwin, Ricardo R. (1999). Umwelts and artificial devices. In $2^{\circ}$ Seminário Avançado de Comunicação e Semiótica: Novos Modelos de Representação: Vida Artificial e Inteligência Artificial, Rogerio da Costa and Lucia Santaella (eds.), 51-56. São Paulo: Programa de Pós-Graduaão em Comunicaão e Semiótica, Pontifícia Universidade Católica.

Nöth, Winfried (1997). Representation in semiotics and in computer science. Semiotica 115 (3/4), 203-223.

- (2000). Handbuch der Semiotik, vol. 2. Stuttgart: Metzler.

Peirce, Charles Sanders (1931-1958). Collected Papers of Charles Sanders Peirce, 8 vols., ed. by Charles Hartshorne, Paul Weiss, and A. W. Burks. Cambridge, MA: Harvard University Press. [Reference to Peirce's papers will be designated $C P$.]

Uexküll, Jakob von (1982 [1940]). The theory of meaning. Semiotica 42 (1), 25-82.

Uexküll, Thure von (1982). Glossary [to Jakob von Uexküll's theory of meaning]. Semiotica $42(1), 83-87$.

Winfried Nöth (b. 1944) is Professor at the University of Kassel in Germany, and Visiting Professor at the Catholic University of São Paulo, Brazil〈noeth@hrz.uni-kassel.de〉. His research interests include semiotics. His major publications include Handbook of Semiotics (1990, 2000), Origins of Semiosis (1994), Semiotics of the Media (1997), and Imagem: Cognição, Semiótica, Mídia (with L. Santaella Braga, 1998). 